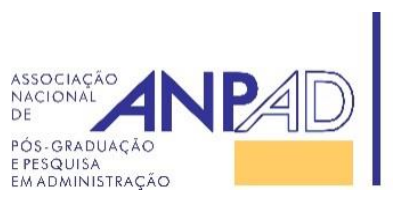
Disponível em
http://www.anpad.org.br/rac
RAC, Rio de Janeiro, v. 21, n. 5, art. 3,
pp. 648-665, Setembro/Outubro, 2017
http://dx.doi.org/10.1590/1982-7849rac2017160179
$($ (c) $)$ EY

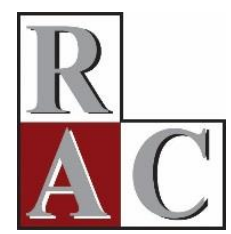

\title{
Court Caseload Management: The Role of Judges and Administrative Assistants
}

Adalmir Oliveira Gomes
${ }^{1}$
Tomas Aquino Guimaraes $^{1}$
Luiz Akutsu $^{1}$

Universidade de Brasília ${ }^{1}$

Artigo recebido em 12.07.2016. Última versão recebida em 23.01.2017. Aprovado em 25.01.2017. Publicado online em 28.04.2017. 


\title{
Resumo
}

A gestão do acervo de processos pendentes em tribunais é essencial para garantir que os processos serão julgados de maneira célere, e isso depende de como juízes e assistentes administrativos lidam com suas cargas de trabalho. Resultados de diversos estudos indicam que um aumento no acervo de tribunais tende a gerar um aumento na produção judicial dos juízes. Entretanto alguns autores apontam que essa relação é mais complexa do que aparenta. No intuito de desenvolver um entendimento mais aprofundado dessa relação, é testado, neste trabalho, um conjunto de hipóteses diretas e de moderação. Foram utilizados dados secundários referentes a 566 juízes que trabalham em varas de primeira instância da Justiça Estadual de São Paulo, Brasil. Os resultados indicam uma relação direta e positiva entre o acervo da vara e a produção dos juízes, mas a força dessa relação varia de acordo com a especialidade da vara. Os resultados também mostram que a quantidade de assistentes administrativos, a experiência e os locais em que o juiz atua moderam a relação entre acervo e produção judicial. Os resultados contribuem para o desenvolvimento de estratégias gerenciais a fim de enfrentar o congestionamento de tribunais brasileiros.

Palavras-chave: judiciário; gestão de tribunais; juízes; produção; acervo.

\begin{abstract}
Court caseload management is of key importance for guaranteeing the adjudication of cases and depends on how judges and administrative assistants deal with their workload. Results from several studies indicate that an increase in court caseload tends to generate an increase in the judge's production. However, some authors argue that this relationship is far more complex. To develop a fuller understanding of this relationship we tested an array of direct and moderating hypotheses. We used secondary data from 566 judges working in first trial courts in the State Justice System of Sao Paulo, Brazil. The results indicate a direct and positive relationship between court caseload and judge production, but the strength of this relationship depends on court specialty. The findings also indicate that the number of administrative assistants, judge experience and the number of places a judge works all moderate the caseload-production relationship. The results contribute to the development of strategies to address the delays and congestion of courts, two of the main Brazilian Judiciary problems.
\end{abstract}

Key words: judiciary; court management; judges; production; caseload. 


\section{Introduction}

One of the major problems faced by courts in several countries is the delay in trial proceedings. The delay stems from an imbalance between high demand and insufficient capacity in the courts. When court caseloads exceed capacity, courts become congested. And when this situation persists for a long period of time, as in Brazilian courts, the delay to reach trial becomes a huge problem that affects virtually all sectors of society.

To manage court caseloads it is necessary to understand the relationship between the demand for legal services and the productive capacity of the courts, especially the judge's capacity. Several studies (Beenstock \& Haitovsky, 2004; Castro, 2011; Dimitrova-Grajzl, Grajzl, Sustersic, \& Zajc, 2012; ElBialy, 2011; Rosales-Lopez, 2008) found a positive relationship between those variables in different courts from different countries. Although these studies are important, they have been the target of many critics, who claim, for example, that the investigated relationship is much more complex than has been presented (Jonski \& Mankowski, 2014).

In this sense, to fully explain the complex relationship between caseload and judicial performance it is necessary to consider some points. Firstly, the context in which the relationship occurs must be taken into account. A description of the context includes several factors, such as the location of the court, its relevance to the judicial system, and its legal specialty, such as civil or criminal justice. Secondly, it is necessary to identify the factors that influence the characteristics of the caseload-performance relationship, making it weaker or stronger.

The objective of this paper is to test an array of direct and moderating hypotheses in order to explain how the relationship between court caseload and judicial performance operates. We used two different variables to measure judicial performance, both associated with judge production: the number of sentences and the number of hearings held by judges in a given period of time. We used secondary data from 566 judges working in first level trial courts in the State Justice System of Sao Paulo, Brazil, the largest and most important state justice system in the country. The following section provides a brief description of the Brazilian State Justice.

\section{Brazilian State Justice}

The Brazilian Judicial System can be divided into two branches: ordinary and special justice. Ordinary justice is further divided into state and federal levels, while special justice encompasses labor, electoral and military matters. The state justice system is composed of trial courts, where cases are initiated, and appeal courts, where decisions handed down in the trial courts are reviewed. According to the Brazilian Federal Constitution, all cases that are not in the jurisdiction of special and federal court justices should be tried in state courts.

The Brazilian State Justice System consists of 27 appeal courts, one in each state capital, and approximately 9,600 trial courts, named vara, spread across many cities in the country. The State Justice System of Sao Paulo is comprised of approximately 1,800 judicial units including trial courts and appeal courts. The trial courts can be classified according to their legal specialty, although some are called mixed trial courts because they deal with cases from different legal specialties, such as civil, criminal, and family (Conselho Nacional de Justiça [CNJ], 2013).

The Brazilian State Justice workforce consists of approximately 11,300 judges working in the first and second level courts, approximately 5.6 state judges for every 100,000 inhabitants (CNJ, 2016). This proportion increases to 8 judges for every 100,000 inhabitants taking into account the judges of all segments of the Brazilian judiciary (approximately 16,000 judges). Even so this remains low compared 
to countries that have also adopted the system of civil law, such as Portugal (19 judges/100,000 inhabitants), Spain (10.7 judges), and Italy (10.2 judges).

One of the great challenges of the Brazilian State Justice System is to increase people's access to legal services, and, at the same time, resolve the huge amount of pending cases, around 80 million in 2015, in all segments of the Brazilian Judiciary. In 2013 alone nearly 27 million new cases were filed, and over three quarters of these were concentrated in the trial courts (CNJ, 2016). To aggravate the problem, judges' working conditions vary considerably, even among courts within the same city. There are courts where facilities are inadequate, and "many judges are obliged to perform their activities in improvised and poorly equipped buildings" (Dallari, 2008, p. 160, our translation).

Brazilian courts have faced an imbalance between the demand for legal services and their judicial production capacity. This imbalance has greatly increased congestion in courts and is a sign that the courts and judges' capacity has been exhausted. According to the Brazilian National Council of Justice (CNJ, 2015), the Brazilian judges are among the most productive in the world. For example, when compared to European judges, each Brazilian judge produces on average 1,600 sentences per year, while in Italy the annual production average is 960, in Spain, 690, and in Portugal, 400.

Besides having an increase in the workload after the 1988 Constitution, the Brazilian judges began to play new roles in the Judiciary and in society. Along with the traditional role, restricted to the application of the laws, the judges began to perform other roles, such as managers, political actors and social activists (Gomes, Guimaraes, \& Souza, 2016). The judge's relationship with public administration has also changed in recent years, with the emergence of a group of more active and participative judges regarding public policies (Osorio \& O'Leary, in press). These changes imply an increase in pressure on judges, with charges coming from society, government and the judiciary itself, demanding fast and high quality judicial service. In this study we investigate how judges respond to this pressure. We also investigate judges who work in different regions and courts of Portugal, who have different attributes and resources to carry out their work. The following section shows how the relationship between court caseload and judicial performance has been addressed in recent literature.

\section{Court Caseload and Judicial Performance}

The mathematical model used by Beenstock and Haitovksy (2004) to explain the relationship between court caseload and judge performance is based on the concept of rational homo economicus. In this concept, judges are seen as individuals seeking to maximize their expected utility and minimize the effort required for case adjudication. The idea of homo economicus to explain judges' behavior was originally used in the works of Posner (2000) and Cooter (1983). According to Jonski and Mankowski (2014), the model used by Beenstock and Haitovksy (2004) must be viewed with care, therefore, even acting as homo economicus, judges draw negative utility from increasing caseloads, because this may diminish their prestige and prospects for promotion and incentives. Thus, Jonski and Mankowski (2014) point out that the central mechanism behind the model is the trade-off between increasing effort and improving performance, or slow down the work pace and take the risk of being exposed negatively in court.

Several studies (Castro, 2011; Dimitrova-Grajzl et al., 2012; El-Bialy, 2011; Rosales-Lopez, 2008) found evidence that a judge's pace of work depends on the existing demand. This approach became known as the hypothesis of exogenous productivity. Rosales-Lopez (2008), for example, investigated lower-level civil courts in Spain to examine why some courts produce more sentences than others. The author concluded that demand plays an important role, since an increase in caseload tends to result in increased court production. Dimitrova-Grajzl, Grajzl, Sustersic, and Zajc (2012) investigated how caseload and workforce influenced the production of Slovenian courts. They found evidence that an increase in judicial demand generates an increase in the court's production. The study of El-Bialy 
(2011), conducted in appeals courts of Egypt, also indicated that the caseload has a direct and positive effect on court's productivity.

Castro (2011) carried out one of the few empirical studies that set out to investigate the relationship between court caseload and judicial performance in the Brazilian Judiciary. Lower-level trial courts of the State Justice System were the unit of analysis. The results showed that when caseload increases in trial courts, individual judge production increases as well. According to Castro (2011), the legal system has self-regulating production mechanisms, so "when the load of pending proceedings increases, the volume of work also increases, preventing the stock from entering an explosive route" (p. 59 , our translation).

The studies presented above have been the target of much criticism. Jonski and Mankowski (2014), for example, point to methodological problems in Beenstock and Haitovsky (2004). According to Jonski and Mankowski (2014), the "so called 'exogenous productivity of judges' hypothesis might be attributed to a modeling flaw, ... originating in neglecting time constraints faced by judges or in $a d$ hoc application of specific functional form, without in-depth consideration of their plausibility" (p. 70). Those authors also suggest that: "Contrary to the views promulgated by the prophets of the "exogenous productivity', judges operate in the universe where adjudication takes time and a day lasts no more than 24 hours" (p. 70). They explain that the judicial productivity is objectively constrained, and, "when these constraints are met, additional staffing or procedural streamlining is necessary to avoid backlog explosion" (Jonski \& Mankowski, 2014, p. 70).

Moreover, it is important to note that in the case of the Brazilian judiciary, after a few years of growth the productivity of judges began to decrease (CNJ, 2016). This may be an indication that the limit of the productive capacity of these professionals has been reached. An excessive workload on judges and other staff can be well tolerated at specific times to respond to unforeseen events that interfere with the proper functioning of the courts. However, most Brazilian judges are constantly overloaded, considering the number of cases they need to resolve (CNJ, 2015). Studies from occupational psychology have shown that stimuli that cause stress at work reinforce workers' negative emotions (Mackie, Holahan, \& Gottlieb, 2001). Thus, when demands and the workload on the professional are excessive, negative emotions tend to intensify (Jex, 1998; Paschoal, Torres, \& Porto, 2010). This may be happening with Brazilian judges, with direct repercussions on the performance of the courts.

Because of this context we believe that the relationship between caseload and judge performance is more complex than it seems, and that this complexity involves judges' personal characteristics and the context in which the work is performed. Thus, to explain how this relationship operates, we investigated judges from different kinds of specialty courts (e.g., mixed courts, civil courts and criminal courts), from different levels (trial courts and appeal courts), and different locations.

Even considering the complexity that involves judges' judicial production, it is necessary to observe the quantitative data used in this research, as well as the definition of judicial production, as proposed by the CNJ. The data used follow an objective logic, which, in a way, relegates subjectivism and the complexity of a judge's work. So, following this line, the numbers speak for themselves, as the specific context in which the numeric data were generated did not exist (Han, 2015). The results of this assumption is that the belief in the measurability and quantification of judicial life can lead to distortions of reality (Han, 2015), since the data and the numbers do not tell us anything about the cases because the numbers are not a narrative. The CNJ's efforts have promoted a performance logic, in which judges regulate and watch over the behavior of their peers, establishing thus a competition culture in which each decision shall be monitored by some efficient technological mechanism. Thus, the quantitative performance and the achievement of production goals takes the place of quality. This cultural change has been highly criticized by many judges (Gomes, Guimaraes, \& Souza, 2016).

Qualitatively evaluating the production of judges is not an easy task, first because this prerogative lies with superior court judges, and second because a court decision involves distinct parts that usually leave the litigation process with different perceptions. The evaluation based on quantitative indicators is easier, since the merit of judicial decisions is not taken into consideration. Nevertheless, some studies 
(Buscaglia, 2001; Djankov, La Porta, Lopez-de-Silanes, \& Shleifer, 2001) point to a positive correlation between efficiency and quality of court decisions. Despite all the problems involving the use of quantitative data to evaluate judges, Abramo (2010) sums up the researcher situation by stating that "the fact that objective measures are not sufficient to assess the judiciary cannot be used as an excuse not to measure what can be measured" (p. 425, our translation).

\section{Theoretical model and research hypotheses}

Based on results of previous studies (Beenstock \& Haitovsky, 2004; Castro, 2011; DimitrovaGrajzl et al., 2012; El-Bialy, 2011; Rosales-Lopez, 2008) we offer an array of related hypotheses concerning the complex interactions between court caseload and judicial performance. Judicial performance is defined as the judicial production of judges. The hypotheses offered in the following paragraphs involves direct and moderating effects, and together they represent this research's theoretical model.

The first hypothesis (H1) concerns the direct relationship between court caseload and judge production. Many studies support this first hypothesis (Beenstock \& Haitovsky, 2004; Castro, 2011; Dimitrova-Grajzl et al., 2012; El-Bialy, 2011; Rosales-Lopez, 2008) that can be expressed as follows.

Hypothesis 1: Court caseload is positively associated with judge production.

Studies on the management of Brazilian courts have emphasized several themes, such as judges' leadership (Vieira \& Costa, 2013), organizational learning (Capaverde \& Vazquez, 2015), impact of new technologies (Freitas \& Medeiros, 2015), adoption of administrative innovations (Guimaraes, Odelius, Medeiros, \& Santana, 2011), among others. Despite the variety of issues addressed, little attention has been paid to the impact of the workforce available in the courts in the management of court caseload.

In Brazil, judges are usually responsible for the administration of judicial units, and to accomplish this task judges rely on the help of a support team of administrative assistants. In certain cases, the judges also rely on the assistance of other judges, usually newly hired, called substitute judges. A survey conducted by the Brazilian Magistrates' Association (Associação dos Magistrados do Brasil [AMB], 2009) revealed that a shortage of administrative assistants is one of the biggest problems faced by judges in Brazil. Thus, the allocation of administrative assistants is an important matter, and may affect directly the judicial production of courts and judges.

The available workforce has been mentioned as a positive factor to increase the judicial performance of courts (Chaparro \& Jiménez, 1996; Gomes, Guimaraes, \& Akutsu, 2016; Mitsopoulos \& Pelagidis, 2007; Schneider, 2005). For instance, Chaparro and Jiménez (1996) found that a larger administrative workforce provides better working conditions for judges, while Mitsopoulos and Pelagidis (2007) found that good administrative support could help to speed the work of the courts. In the Brazilian Judiciary, Gomes, Guimaraes, and Akutsu (2016) used longitudinal data (2003 to 2012) for all state courts to investigate the impact of hiring new judges and administrative assistants on court performance. The main findings indicate that the number of judicial assistants has a positive influence on court productivity, and the number of assistants mitigates the positive relationship between court caseload and court productivity.

Thus, based on those previous studies, it is expected that the relationship between court caseload and judge production is strengthened by the number of administrative assistants in the court. Following the same logic, it is expected that the number of administrative assistants positively moderate the strength of the caseload-production relationship. This means that an increase in the number of assistants in a court tends to strengthen the relationship between court caseload and judge production. Thus, the second and third hypothesis ( $\mathrm{H} 2$ and $\mathrm{H} 3)$ can be expressed as follows.

Hypothesis 2: The number of administrative assistants is positively associated with judge production. 
Hypothesis 3: The number of administrative assistants positively moderates the relationship between caseload and judge production, so that an increase in the number of administrative assistants increases the strength of this relationship.

Several studies (Bhattacharya \& Smyth, 2001; Smyth \& Bhattacharya, 2003; Taha, 2004; Teitelbaum, 2006) indicate a positive correlation between judge experience and performance, although this correlation only makes sense up to a certain age, as is the case in many other professions. However, some findings indicate that this correlation is far more complex. For example, Backes-Gellner, Schneider, and Veen (2011) investigated appeals court judges in Germany, and found that age and experience positively influence only the qualitative performance of judges. An opposite effect was observed when considering the quantitative performance, so that the most experienced judges are less productive than the younger ones.

In Brazil, as judges advance in their careers, they move from mixed and peripheral courts to central and specialized courts, where working conditions tend to be better and the workload tends to be lower (Resolução $\left.n^{\circ} 106,2010\right)$. In this situation, the more experienced judges tend to slow down the pace of work (e.g., Backes-Gellner, Schneider, \& Veen, 2011). However, on the other hand, the most experienced judges theoretically had more time than younger ones to develop necessary skills and expertise in judicial activities, so they tend to have more agility in the execution of judicial activities, which can positively influence production.

Thus, we expect that judges' experience directly and indirectly influences the way their professional activities are carried out. Although there are opposing arguments, we follow the results of most previous studies on the subject. In this sense, we expect that judge experience negatively affects judicial production. Similarly, we also expect that judge experience negatively moderates the relationship between caseload and judge production, as described in the following hypothesis ( $\mathrm{H} 4$ and H5).

Hypothesis 4: Judge experience is negatively associated with judge production.

Hypothesis 5: Judge experience negatively moderates the relationship between caseload and judge production, so that an increase in experience decreases the strength of this relationship.

And the last variable tested in this study is the number of places a judge works, which we call judge workplace. This variable represents the number of courts or judicial units in which a judge is responsible and works simultaneously. Although this probably does not make sense in some countries, in Brazil this is relevant in almost all segments of the judiciary. Many judges have to travel daily to work in different judicial units located in different cities. It requires time and energy that could be used by judges in other activities, or devoted to rest and recreation. On the other hand, it is reasonable to assume that it does not make much difference where a workplace is, because the work itself is the same, which would represent a null relationship between the number of places a judge works and judge production.

Just as with the relationship between experience and production, there are also opposing arguments to the relationship between number of workplaces and production. Anyway, as we did not find empirical studies about this relationship, we believe that time is an important variable in this dilemma, so that the simple fact that judges have to constantly travel to work in different locations does more harm than benefit to the output of their judicial production. Thus, we assume that when judges simultaneously work in various courts their ability to produce sentences and hold hearings will be affected. In this sense, the following hypothesis (H6 and H7) suggests that the number of places a judge works affects negatively judge production, and moderates negatively the relationship between caseload and judge production.

Hypothesis 6: The number of places a judge works is negatively associated with judge production. 
Hypothesis 7: The number of places a judge works moderates negatively the relationship between caseload and judge production, so that an increase in the number of workplaces decreases the strength of this relationship.

Figure 1 shows the study's theoretical model and the hypotheses described in the previous paragraphs. First, there is a direct hypothesis (H1) about the relationship between caseload (X) and judge production (Y). Hypotheses $\mathrm{H} 2, \mathrm{H} 4$ and $\mathrm{H} 6$ involve the direct effect of the others explanatory variables on judge production; and hypotheses $\mathrm{H} 3, \mathrm{H} 5$ and $\mathrm{H} 7$ (dashed arrows) involve indirect effects of the moderator's variables $\left(\mathrm{M}_{1}, \mathrm{M}_{2}\right.$ and $\left.\mathrm{M}_{3}\right)$ on the relationship hypothesized in $\mathrm{H} 1$. In Figure 1, the arrows represent the expected relationships among the model variables. Hayes (2013) teaches that "arrows denote predictor of, meaning that if an arrow points from variable $\mathrm{A}$ to variable $\mathrm{B}$, then variable $\mathrm{A}$ is a predictor variable in the statistical model" (p. 4). The same author argues that "in path diagram representation, the arrows need not be interpreted in causal terms, although they may be if that is the intent of the analyst" (Hayes, 2013, p. 4).

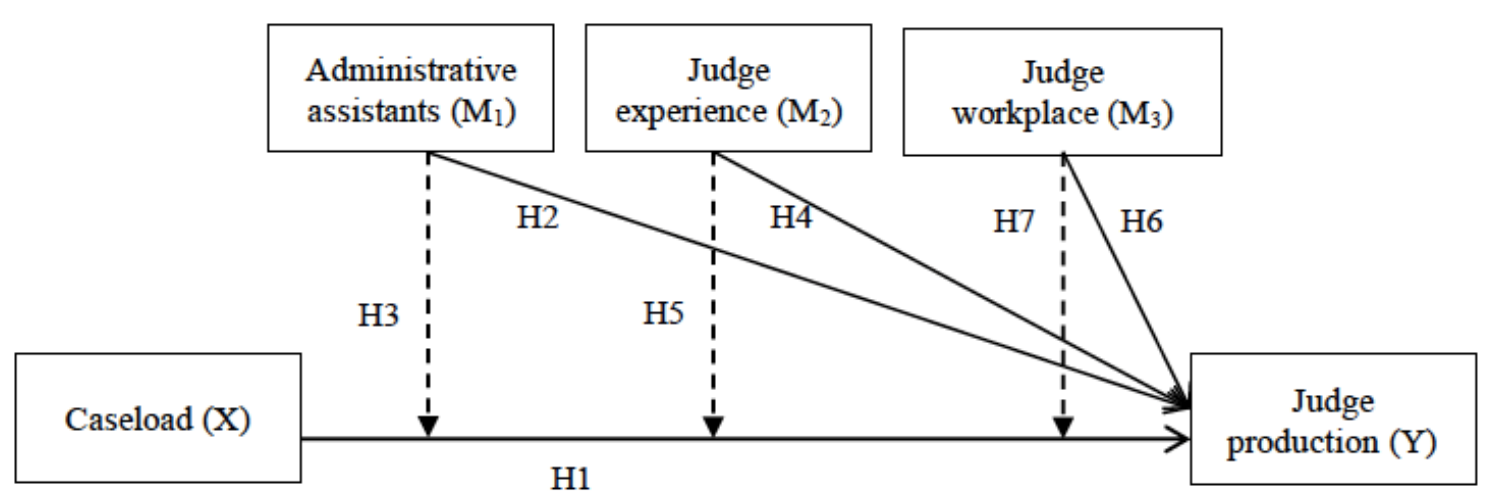

Figure 1. Theoretical Model and Research Hypotheses

Source: Prepared by the authors.

Certainly there are many intervening variables in the hypothesized relationships, which could lead, for example, to endogeneity problems, that is, omission of relevant variables in the models estimated. These intervening variables include, for example, personal characteristics of the judges, such as age, professional formation, and motivation to mature a career; personal characteristics of administrative assistants, such as education and training; contextual characteristics, such as the physical structure of the court, the litigation rate, and the economic and financial situation of the municipality where the court operates; and characteristics of judicial proceedings, such as the complexity and the time that a case has been waiting to be judged. Unfortunately, we do not have access to these variables. In Brazil, the systematic collection of data by the Judiciary started only in the 2000s, especially after the creation of the CNJ in 2005, and thus the data available are very limited, which restricts the possibility of deeper analysis (Gomes \& Guimaraes 2013).

\section{Method}

This study investigates first level trial courts of the State Justice System of São Paulo, Brazil. The secondary data refer to 2013 and were collected from the Open Justice system (www.cnj.jus.br/programas-e-acoes/justica-aberta), a database developed by the CNJ and supplied monthly with information from all judicial units in the country. The Open Justice provided data on court caseload, court performance, and administrative workforce. Additional information comes from the State Justice System of Sao Paulo - TJSP (www.tjsp.jus.br), which provided data on the judges' experience and workplaces. 
In 2013, 2044 judges were working at State Justice System of São Paulo, including 1742 titular judges and 302 substitute judges. We selected a random sample of 566 titular judges: 144 judges working in mixed trial courts, 308 in civil courts, and 114 in criminal courts. We selected only titular judges because they are the central actors in the courts where they work. Titular judges are responsible for managing the court caseload, the administrative workforce, and all the available resources.

The dependent variables represent judicial production. We used two variables to measure judge production: sentences $\left(\mathrm{Y}_{1}\right)$, and hearings $\left(\mathrm{Y}_{2}\right)$. The former is measured by the number of sentences stated by a judge each month, without considering the type of sentence. It is important to mention that we did not exclude from the total sentences those that only dismissed a case, i.e., without deciding its merits. This is an important criticism of the quantitative approach to court performance, and to CNJ quantitative goals (CNJ, 2013; Sena, 2014), as it may artificially encourage this sort of sentence by judges. We understand that there is an effort by judges for every kind of sentence, regardless of resolving the merit. And the second dependent variable is the number of cases a judge hears each month. This is an important judicial production indicator since many of the court cases depend on the hearings, and this task requires time, attention and effort by judges.

The court caseload $(\mathrm{X})$ is the main explanatory variable, measured by the total number of pending cases awaiting judgment in the trial court. The other explanatory variables are the following: administrative assistants, measured by the number of administrative assistants in trial courts; judge experience, measured by the years that a judge has been working in the profession; and judge workplace, measured by the number of places where a judge works concomitantly. Table 1 shows the descriptive statistics of the variables.

Table 1

\section{Descriptive Statistics of the Variables}

\begin{tabular}{lcccc}
\hline \multicolumn{1}{c}{ Variables } & $\begin{array}{c}\text { Mixed } \\
(\mathrm{N}=144)\end{array}$ & $\begin{array}{c}\text { Civil } \\
(\mathrm{N}=308)\end{array}$ & $\begin{array}{c}\text { Criminal } \\
(\mathrm{N}=114)\end{array}$ & $\begin{array}{c}\text { Total } \\
(\mathrm{N}=566)\end{array}$ \\
\cline { 2 - 5 } & Mean (S.d.*) & Mean (S.d.) & Mean (S.d.) & Mean (S.d.) \\
\hline Sentences (per month) & $122(47)$ & $122(46)$ & $64(35)$ & $110(51)$ \\
Hearings (per month) & $49(18)$ & $31(26)$ & $72(25)$ & $44(29)$ \\
Caseload (in thousand) & $10(5.6)$ & $8.6(3.8)$ & $4.5(2.8)$ & $8.2(5.3)$ \\
Administrative assistants & $14(5.1)$ & $14(5.3)$ & $11(4.0)$ & $13(5.1)$ \\
Judge experience (in years) & $8.7(3.2)$ & $17(5.3)$ & $16.7(6.3)$ & $15(6.6)$ \\
Judge workplace (unit) & $3.2(1.7)$ & $2.5(1.4)$ & $2.7(1.6)$ & $2.7(1.6)$ \\
\hline
\end{tabular}

Note. Source: prepared by the authors.

*Standard deviation.

We used regression analysis to estimate the relationship between the exploratory variables and judge production, and thus to test the direct hypotheses ( $\mathrm{H} 1, \mathrm{H} 3, \mathrm{H} 5$ and $\mathrm{H} 7)$. The estimation model used was ordinary least squares (OLS). To test the moderation hypotheses (H2, H4 and H6) we used conditional analysis. In a regression model given by the equation 1 , the effect of $X$ on $Y$ is fixed to be the same (b1), independent of the value of $W$.

$$
Y=b_{0}+b_{1} X+b_{2} W
$$

According to Hayes and Rockwood (in press), this can be a serious analytical constraint. In order to use regression analysis to test a moderation hypothesis, the constraint on $X$ 's effect must be released. This can be achieved through specifying $X$ 's effect to be a linear function of $W$. Thus, replacing $b_{1}+$ $b_{3} W$ for $b_{1}$ in the above equation, the result is the equation 2 (Hayes \& Rockwood, in press). 


$$
Y=c+\left(b_{1}+b_{3} W\right) X+b_{2} W
$$

Which is mathematically equivalent to equation 3 .

$$
Y=c+b_{1} X+b_{2} W+b_{3} X W
$$

A test of linear moderation is conducted with a hypothesis test for the regression coefficient for $X W$, that is, an inference about whether the weight for $W$ in the linear function defining $X$ 's effect $\left(b_{1}+\right.$ $b_{3} W$ ) is equal to zero. If $b 3$ is different than zero, this means that $X$ 's effect on $Y$ varies with $W$ (Hayes \& Rockwood, in press, p. 29).

We carry out several residuals analyses to investigate the suitability of the regression models presented in this study: normality tests were done to verify if the variables follow normal distributions; Durbin-Watson test to verify the independence of the residuals; and Breusch-Pagan and GoldfeldQuandt test to verify if the residuals are homoscedastic. The results of these tests did not indicate any lack of fit of the regression models and the assumptions associated with them.

\section{Results and Discussion}

The regression results indicate that, regardless of the trial court specialty, there is a direct and positive relationship between court caseload and judge production (see Table 2). This means that an increase in caseload generates an increase in the amount of sentences and hearings. These findings were expected and supported by previous studies (Beenstock \& Haitovsky, 2004; Castro, 2011; DimitrovaGrajzl et al., 2012; El-Bialy, 2011; Rosales-Lopez, 2008) that found evidence that a judge's pace of work depends on the demand for justice services. This first result is evidence for the hypothesis of exogenous productivity (Beenstock \& Haitovsky, 2004; Castro, 2011; Dimitrova-Grajzl et al., 2012; ElBialy, 2011; Rosales-Lopez, 2008). Nevertheless, it must be emphasized that the strength of the relationship varies considerably depending on the specialty of the trial court.

Results of regression analysis (see Table 2) show that the strongest relationship observed was between caseload and sentences in mixed trial ( 0.612 regression coefficient). This means that when court caseload increases by one standard deviation, which represents an increase of 5.6 thousands of cases, the average number of sentences per judge increases 0.612 standard deviations. This increase generated in production represents 28.7 sentences per month, an increase of almost $20 \%$ over the average production of judges, which is 144 sentences per month. 
Table 2

Results of Multiple Regression Analysis

\begin{tabular}{lllllll}
\hline Explanatory variables & \multicolumn{3}{l}{ Dependent variables ${ }^{\mathrm{a}}$} \\
\cline { 2 - 7 } & \multicolumn{2}{l}{ Mixed } & \multicolumn{3}{l}{ Civil } \\
\cline { 2 - 7 } & Sentences & Hearings & Sentences & Hearings & Sentences & Hearings \\
\hline Caseload & $.612^{* *}$ & $.208^{*}$ & $.084^{*}$ & $-.138^{*}$ & $.347^{* *}$ & $.273^{*}$ \\
Administrative assistants & .018 & .049 & .046 & -.055 & .078 & -.099 \\
Judge experience & .075 & .064 & $-.209^{* *}$ & -.027 & $-.126^{*}$ & $-.201^{*}$ \\
Judge workplace & -.009 & $.074^{*}$ & -.029 & -.048 & .066 & $-.110^{*}$ \\
Constant b c & $75.8(11.5)$ & $38.2(5.5)$ & $99.4(12.8)$ & $47.2(7.4)$ & $41.8(19.9)$ & $57.2(11.6)$ \\
F (anova) & $16.7^{* *}$ & $8.9^{*}$ & $4.3^{* *}$ & $2.1^{* *}$ & $5.9^{* *}$ & $3.6^{* *}$ \\
Adjusted $\mathrm{R}^{2}$ & .47 & .26 & .41 & .19 & .32 & .14 \\
\hline
\end{tabular}

Note. Source: Prepared by the authors. N: 566.

${ }^{\mathrm{a}}$ Standardized regression coefficient $(\beta),{ }^{\mathrm{b}}$ Nonstandard regression coefficient; ${ }^{\mathrm{c}}$ Standard error in brackets $* \mathrm{p}<.05 ; * * \mathrm{p}<.01$

Hypothesis 1 is supported in all trial courts when the dependent variable is sentences, and in mixed and criminal trial courts when the dependent variable is hearings. The only exception is a negative relationship between caseload and hearings in civil trial courts. In this case, when the caseload increases, the number of hearings tends to decrease. The explanation for this particular result is that hearings are not essential procedures in the civil courts, such as the case of the criminal trial courts. Thus, in certain situations, when demand increases, the judges can reduce the time spent with hearings in order to prioritize the judgments.

Among the other explanatory variables, only judge experience had a direct and negative effect on judge production, and this happens only in some situations. As can be seen in Table 2, the more experienced the judge, the lower the production of sentences in civil courts; and the lower the production of sentences and hearings in criminal courts. The other explanatory variables did not present statistically significant direct effect on judge production.

The results of conditional analysis show that the direct relationship observed between caseload and judge production is moderated by all the explanatory variables investigated: administrative workforce, judge experience, and judge workplace. The strength of the court caseload-production relationship depends on these moderating variables, and the moderating effects vary according to trial court specialty. This result was also expected because there are considerable differences in the work performed by judges in different court specialties, for instance, the need to deal with different legal expertise, the number and the complexity of the legal requirements, and the duration of procedures. Because of this, we present the results in the following paragraphs separately for each trail court - mixed, civil and criminal.

The mixed trail courts are judicial units usually located in small towns, receiving cases from different legal specialties. The judges in these courts work in worse conditions than their colleagues in specialized courts. The main differences in working conditions are a high caseload, unprepared workforce and poor physical facilities. In mixed trail courts, the caseload is on average $15 \%$ higher than the caseload of civil trial courts, and 55\% higher than the caseload of criminal trial courts (see Table 1). This means that a case is likely to take longer to be judged if it is filed in a mixed trial court.

As the mixed trail courts are located in small towns there is a clear difference in the workforce. The judges working in these units are generally in the early years of their career (average of 8.7 years), with relatively little experience, but with great incentives to work and improve their conditions and 
advance their careers. Other characteristics of mixed trail courts are the high turnover of judges, who usually work for a short time before being transferred to other locations. The average number of administrative assistants in mixed trial courts is 14 , the same number is found in civil courts, and this is slightly higher than the number found in criminal courts, which is 11.

The results for the mixed courts indicate a direct and positive relationship between court caseload and the two variables measuring judge production. The relationship is stronger when the dependent variable is the production of sentences. This means that when the caseload increases judges tend to focus on producing more sentences. The findings indicate that the direct relationship observed between caseload and the dependent variables is moderated by two variables: administrative assistants and judge workplace (see Figure 2).

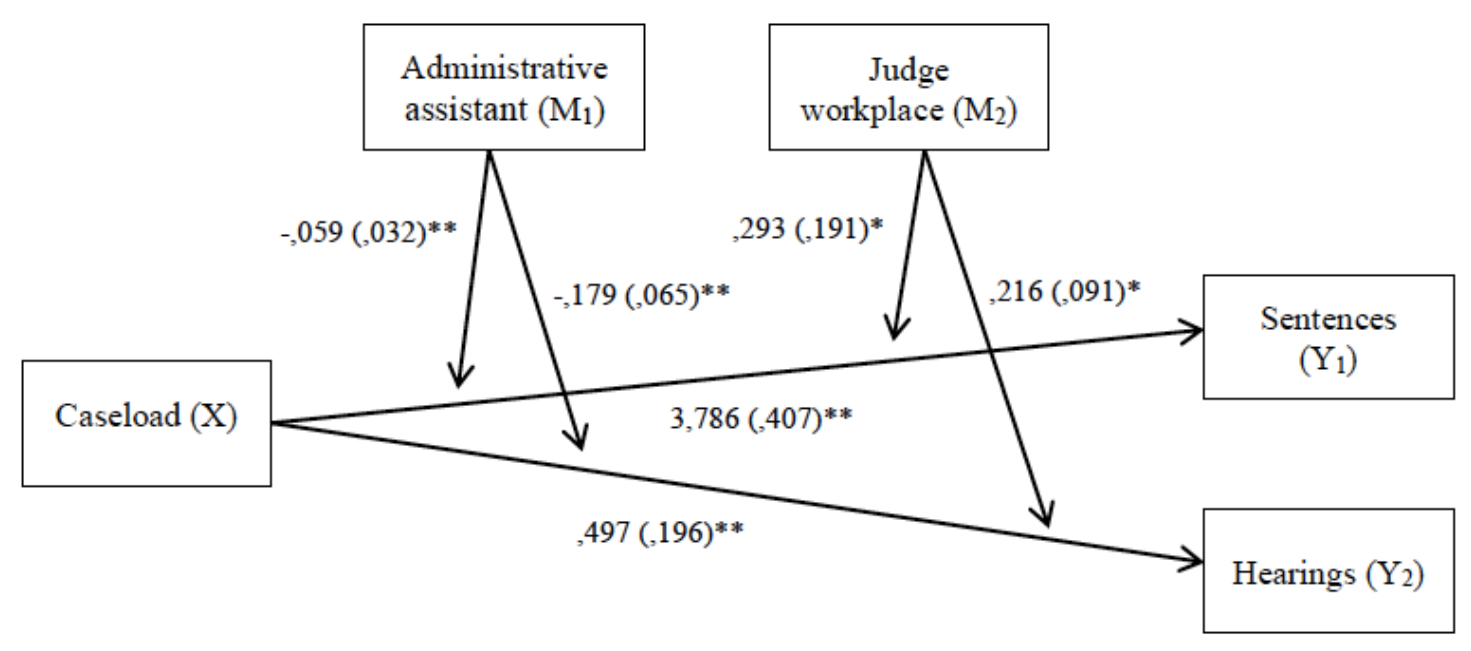

Figure 2. Moderation Model for Judge Production in Mixed Trial Courts Coefficient not standardized (standard error between parenthesis). $\mathrm{p}<.05 ; * \mathrm{*}<.01$.

The results presented in Figure 2 show that the administrative assistants (M1) moderate the relationship between caseload (X) and the two dependent variables - sentences (Y1) and hearings (Y2). In both cases the effect of the moderation is negative, so that the greater the number of administrative assistants, the lower the strength of the positive relationship between caseload and judge production. At first sight, this is an unexpected result, since more administrative employees was hypothesized to be a positive influence on judge production ( $\mathrm{H} 2 \mathrm{e} \mathrm{H} 3)$.

A possible explanation for this finding is that judges who work in small courts tend to assume greater responsibility for the increasing caseload, since they know that the sharing of this responsibility is restricted to a small number of administrative assistants. In other words, when judges have a small number of administrative assistants, such as the case of judges who work in small courts, they work harder than other judges to meet the increasing caseload, both to make judgments as to conduct hearings.

Another moderating variable is the number of places where a judge works concomitantly - judge workplace (M2). Unlike the first moderation, the effect is positive, which means that when judges work concurrently in various places, the relationship between court caseload and judge production tends to be strengthened. This result suggests that judges working in different courts or units tend to have a stronger productive reaction in the event of increasing court caseload. This finding was also unexpected because judges working in a single unit theoretically have more time to devote to the specific judicial activities of this unit, besides not having to move constantly, and because of this advantage they would have more time to devote themselves to judicial production.

A possible explanation for this finding may be the dynamics of the state judge's career in Brazil. Early in their careers, judges work in peripheral units, which usually have a large caseload. Furthermore, these judges must act as substitutes, which involves continually moving among different towns. This 
first stage usually lasts a couple years, after which the judge can be transferred to units with better working conditions, especially in terms of demand. This transfer depends on the judge performance, particularly in terms of judicial production. Another advantage of the career growth consists in the possibility of assuming a single unit, thus avoiding the need to constantly move between different units. This situation helps explain why state judges tend to work harder early in their careers, even in adverse working conditions.

Unlike mixed courts, the specialized courts are usually located in medium and large cities. In these units, the judges are more experienced, with an average of 17 years in the career, and work in better conditions in terms of workload, resources and physical environment. Table 1 shows that the average production of sentences in civil courts, 122 per month, is equal to the average production in mixed courts, and almost double the production verified in criminal courts, where it is 64 per month. On the other hand, the average number of hearings in criminal courts, 72 per month, is more than the double that in civil courts, 31 per month. Regarding caseload, while in civil courts the average caseload is 8,600 cases, in criminal courts it is 4,500 . These differences are mainly due to the characteristics of each court, such as the procedural formalities, the duration of procedures, the participation of witnesses and so on.

The regression analysis for the civil courts indicates a direct and positive relationship between court caseload and sentences; and a direct and negative relationship between court caseload and hearings. This finding indicates that an increase in workload requires the judge reduce the number of hearings in favor of an increase in carrying out sentences. The only moderating variable is the number of administrative assistants. As can be seen in Figure 3, the effect of the moderation is negative, which means that when there are more administrative assistants in the court, the strength of the relationship between caseload and sentences tends to be mitigated. This result is similar to results found in mixed courts.

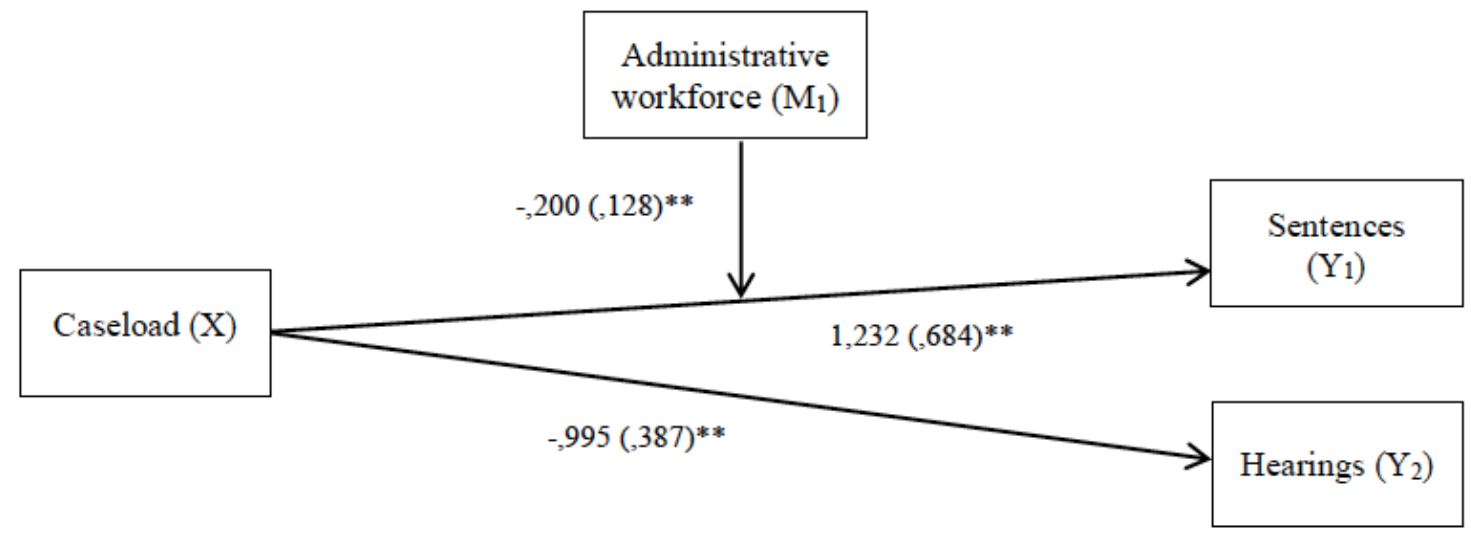

Figure 3. Moderation Model for Judge Production in Civil Trial Courts

Coefficient not standardized (standard error between parenthesis). * $\mathrm{p}<.05 ; * * \mathrm{p}<.01$.

The explanation for this result is the same presented for mixed courts, that is, a high heterogeneity among the civil courts. Thus, there are peripheral units with poor working conditions, with high caseload and few assistants; and on the other hand, central units benefiting from significantly better conditions. Thus, the dynamics of a judge's career in Brazil motivates judges who work in peripheral civil courts to work harder than their colleagues, even with few assistants, in order to advance in their careers and move to central units with better working conditions.

In criminal courts, the results indicate a direct and positive relationship between court caseload and a judge's sentences and hearings. The results of the conditional analysis indicate that the variables judge experience and judge workplace moderate the relationship between caseload and production (see Figure 4). The first variable, judge experience, negatively moderates the relationship between caseload and hearings, so that this relationship tends to be mitigated for old judges. And the second variable, 
judge workplace, positively moderates the relationship between caseload and sentences, so that this relationship tends to be mitigated when the judge works in only one place.

The results indicate that the efforts made by judges in response to an increase in caseload are stronger among less experienced judges who usually work in peripheral criminal courts. The behavior of the more experienced judges does not seem to be influenced by the caseload. This finding can be explained by the supposition that the older judges are more concerned with quality rather than quantity (Backes-Gellner et al., 2011). Another explanation concerns the profile of the most experienced judges, focused primarily on strategic and political issues, and little involved with operational activities (Gomes, Guimaraes, \& Souza 2016).

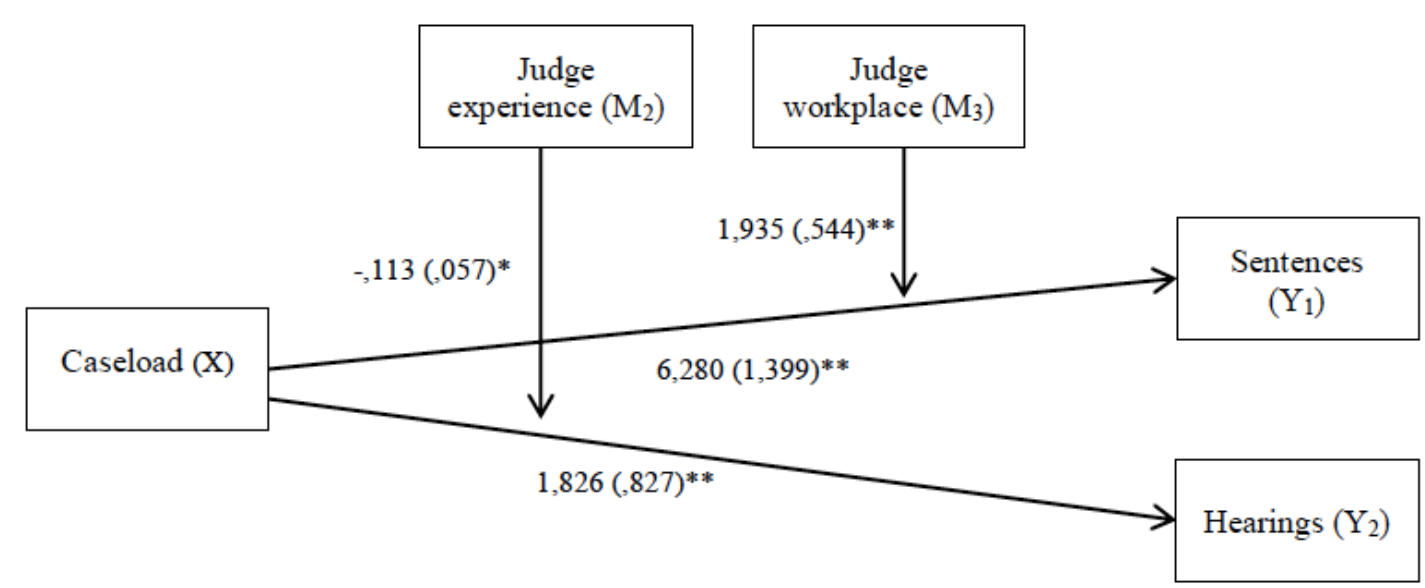

Figure 4. Moderation Model for Judge Production in Criminal Trial Courts

Coefficient not standardized (standard error between parenthesis). *p<.05; **p<.01.

Of the seven hypotheses tested, only the first (H1) - direct relationship between caseload and judge production - was supported in all types of courts. The only exception is a negative relationship between caseload and hearings in civil courts. The second hypothesis (H2) - a direct relationship between assistants and production - was rejected in all samples. The third hypothesis (H3) - moderation by administrative assistants - was confirmed only in mixed courts (hearings); in all other cases the hypothesis was rejected. The fourth hypothesis (H4) - direct relationship between experience and production - was confirmed in civil (sentences) and criminal (sentences and hearings) courts. The fifth hypothesis (H5) - moderation by experience - was confirmed only in criminal courts (hearings); in all other cases the hypothesis was rejected. The sixth hypothesis (H6) - a direct relationship between number of administrative assistants and production, and the seventh hypothesis (H7) - moderation by the number of places judges work, was rejected in all samples.

\section{Concluding Remarks}

This study aims to explain the relationship between court caseload and judge production. The results show that the strength of this relationship, called in an earlier study as the hypothesis of exogenous productivity, depends on court specialty and is moderated by the number of administrative assistants in courts, judge experience and the number of places a judge works. In other words, our findings show that hypothesis of exogenous productivity is much more complex than has been portrayed in previous studies.

The results are important because they help to clarify the mechanism that underpins the phenomenon investigated, that is, the answer of judges and court's employees to situations in which the demand for legal services increases, and consequently the workload increases. The findings help to 
explain how this relationship operates, allowing progress toward more appropriate theoretical models than the existing ones, such as the models suggested by Beenstock and Haitovsky (2004) and Jonski and Mankowski (2014).

The findings need to be viewed with reservation due to the nature of the work done by the judges and the limit of working capacity of these professionals. The demand for judicial services in Brazil has increased consistently since the 1988 Constitution, a situation that has worsened in recent years, as indicated by the $\mathrm{CNJ}$ reports. It would be naive to imagine that the production of judges is able to accompany the increase in demand, and also solve the deficit of pending cases in the courts. According to the CNJ (2016), even if new processes were not filed, it would take about three years to clear the inventory of pending cases in all courts of Brazil. The productive capacity of judges is limited, so that the linear relationship between caseload and production, observed in this study probably does not hold for long. CNJ data itself (2016) seem to indicate that the limit has already been reached in some courts, and is very close to being reached in others.

In practical terms the results are important because they show that the court caseload management strategy cannot be generic to all courts specialty. Instead, the strategy should be specific and will depend primarily on the contextual situation of each court. This means that different strategies should be developed to face the increase in demand for legal services, and this strategy should consider the peculiarities of courts, especially the human resources available.

This study has some limitations, the main one is the lack of data regarding the Brazilian judiciary. In Brazil the systematic collection of data by the judiciary started only in the 2000 's, especially after the creation of the National Justice Council (CNJ) in 2005. The data are, as yet, limited, and restricts the possibility of deeper analysis (Gomes \& Guimaraes, 2013). The limited data hinders, for example, the investigation of whether different types of caseload influence judicial performance, or whether different types of administrative assistants influence the relationship between caseload and judge production. Or even whether other variables and indicators of judicial performance should be used, in addition to the production of sentences and hearings by judges (For methodological issues on court caseload management, see Lienhard \& Kettiger, 2011).

Future studies could investigate other possible intervening variables through qualitative studies, using as data collection, for example, interviews and focus groups. Those studies could compare the findings presented in this study with the opinions of judges and of employees working in the courts investigated. Interviews could help in defining new propositions and hypotheses to be tested. Another suggestion for future research would be to replicate the statistical analyses using samples from other state justice systems in Brazil and in other countries. The results from other contexts would help in the development of a better understanding of the relationships examined in this study.

\section{References}

Abramo, C. W. (2010). Tempos de espera no Supremo Tribunal Federal. Revista Direito GV, 6(2), 423442. http://dx.doi.org/10.1590/S1808-24322010000200004

Associação dos Magistrados do Brasil. (2009). Primeira pesquisa sobre condições de trabalho dos juizes. Brasília: Associação de Magistrados do Brasil, MCI Estratégia.

Backes-Gellner, U., Schneider, M., \& Veen, S. (2011). Effect of workforce age on quantitative and qualitative organizational performance: Conceptual framework and case study evidence. Organization Studies, 32(8), 1103-1121. http://dx.doi.org/10.1177/0170840611416746

Beenstock, M., \& Haitovsky, Y. (2004). Does the appointment of judges increase the output of the judiciary? International Review of Law and Economics, 24(3), 351-369. http://dx.doi.org/10.1016/j.irle.2004.10.006 
Bhattacharya, M., \& Smyth, R. (2001). Ageing and productivity among judges: Some empirical evidence from the High Court of Australia. Australian Economic Papers, 40(2), 199-212. http://dx.doi.org/10.1111/1467-8454.00122

Buscaglia, E. (2001). An economic and jurimetric analysis of official corruption in the courts: A governance-based approach [Working Paper n. 12]. Research and Scientific Series, United Nations - Centre for International Crime Prevention. Viena, Austria.

Capaverde, C., \& Vazquez, A. C. (2015). Implantação de processo eletrônico no Sistema Judiciário: Um estudo sobre aprendizagem organizacional em uma Secretaria de Gestão de Pessoas. Revista Eletrônica de Administração, $\quad 81(2), \quad 462-490 . \quad$ http://dx.doi.org/10.1590/14132311.0592014.53649

Castro, A. (2011). Indicadores básicos e desempenho da Justiça Estadual de primeiro Grau no Brasil. [Texto para discussão n. 1609]. Brasília, DF: IPEA.

Chaparro, F., \& Jimenez, L. (1996). An assessment of the efficiency of Spanish Courts using DEA. Applied Economics, 28(11), 1391-1403. http://dx.doi.org/10.1080/000368496327651

Conselho Nacional de Justiça. (2013). Metas nacionais do Poder Judiciário 2009-2012. Brasília: Autor.

Conselho Nacional de Justiça. (2015). Trabalhar na magistratura, construção da subjetividade, saúde e desenvolvimento profissional. Série Justiça e Pesquisa. Brasília: Autor.

Conselho Nacional de Justiça. (2016). Justiça em números 2015. Indicadores do Poder Judiciário: panorama do Judiciário Brasileiro. Brasília: Autor.

Cooter, R. (1983). The objectives of private and public judges. Public Choice, 41(1), 107-132. http://dx.doi.org/10.1007/BF00124053

Dallari, D. (2008). O poder dos Juízes (3a ed.). São Paulo: Saraiva.

Dimitrova-Grajzl, V., Grajzl, P., Sustersic, J., \& Zajc, K. (2012). Court output, judicial staffing, and the demand for court services: Evidence from Slovenian courts of first instance. International Review of Law and Economics, 32(1), 19-29. http://dx.doi.org/10.1016/j.irle.2011.12.006

Djankov, S., La Porta, R., Lopez-de-Silanes, F., \& Shleifer, A. (2001). Legal structure and judicial efficiency: The Lex mundi project. Washington, DC: World Bank.

El-Bialy, N. (2011). Measuring judicial performance: (The case of Egypt). [Working Paper n. 14]. German Working Papers in Law and Economics, Berkeley, CA.

Freitas, C., \& Medeiros, J. (2015). Organizational impacts of the electronic processing system of the Brazilian Superior Court of Justice. JISTEM Journal of Information Systems and Technology Management, 12(2), 317-332. http://dx.doi.org/10.4301/S1807-17752015000200007

Gomes, A., \& Guimaraes, T. (2013). Desempenho no Judiciário. Conceituação, estado da arte e agenda de pesquisa. Revista de Administração Pública, 47(2), 379-401. http://dx.doi.org/10.1590/S003476122013000200005

Gomes, A., Guimaraes, T., \& Akutsu, L. (2016). The relationship between judicial staff and court performance: Evidence from Brazilian State Courts. International Journal for Court Administration, 8(1), 12-19. http://dx.doi.org/10.18352/ijca.214

Gomes, A., Guimaraes, T., \& Souza, E. (2016). Judicial work and judges' motivation: the perceptions of Brazilian state judges. Law \& Policy, 38(2), 162-176. http://dx.doi.org/10.1111/lapo.12050 
Guimaraes, T., Odelius, C., Medeiros, J., \& Santana, J. (2011). Management innovation at the Brazilian Superior Tribunal of Justice. The American Review of Public Administration, 41(3), 297-302. http://dx.doi.org/10.1177/0275074010380449

Han, B.-C. (2015) Psicopolítca. Lisboa: Relógio D’Água Editores.

Hayes, A. (2013). Introduction to mediation, moderation, and conditional process analysis: A regression-based approach (2nd ed.). New York: Guilford Press.

Hayes, A., \& Rockwood, N. (in press). Regression-based statistical mediation and moderation analysis in clinical research: Observations, recommendations, and implementation. Behaviour Research and Therapy, http://dx.doi.org/10.1016/j.brat.2016.11.001

Jex, S. M. (1998). Stress and job performance. London: Sage Publications.

Jonski, K., \& Mankowski, D. (2014). Is sky the limit? Revisiting 'exogenous productivity of judges' argument. International Journal for Court Administration, 6(2), 53-72. http://dx.doi.org/10.18352/ijca.135

Lienhard, A., \& Kettiger, D. (2011). Research on the caseload management of courts: Methodological questions. Utrecht Law Review, 7(1), 66-73. http://dx.doi.org/10.18352/ulr.147

Mackie, K. S., Holahan, C. K., \& Gottlieb, N. H. (2001). Employee involvement management practices, work stress, and depression in employees of a human service residential care facility. Human Relations, 54(8), 1065-1092. http://dx.doi.org/10.1177/0018726701548004

Mitsopoulos, M., \& Pelagidis, T. (2007). Does staffing affect the time to dispose cases in Greek Courts? International Review of Law and Economics, 27(2), 219-244. http://dx.doi.org/10.1016/j.irle.2007.06.001

Osorio, A., \& O'Leary, R. (in press). The impact of courts on public management: New insights from the legal literature. Administration \& Society, 49(5), 658-678. (Prevision Screen - May/2017). http://dx.doi.org/10.1177/0095399716682329

Paschoal, T., Torres, C., \& Porto, J. (2010). Felicidade no trabalho: relações com suporte organizacional e suporte social. Revista de Administração Contemporânea, 14(6), 1054-1072. Recuperado de http://www.scielo.br/pdf/rac/v14n6/v14n6a05.pdf. 65552010000700005

Posner, R. A. (2000). Is the ninth circuit too large? A statistical study of judicial quality. Journal of Legal Studies, 29(2), 711-719. http://dx.doi.org/10.1086/468090

Resolução $n^{o} 106$ de 06 de abril de 2010. (2010). Dispõe sobre os critérios objetivos para aferição do merecimento para promoção de magistrados e acesso aos tribunais de 20 grau. Brasília: Conselho Nacional de Justiça.

Rosales-Lopez, V. (2008). Economics of court performance: An empirical analysis. European Journal of Law and Economics, 25(3), 231-251. http://dx.doi.org/10.1007/s10657-008-9047-9

Sena, G. A. (2014). Metas do Conselho Nacional de Justiça 2012/2013: Uma análise dos contornos gerenciais assumidos pela reforma do Poder Judiciário no Brasil. Revista do Serviço Público, 65(2), 163-184. http://dx.doi.org/10.21874/rsp.v65i2

Schneider, M. (2005). Judicial career incentives and court performance: An empirical study of the German Labor Courts of Appeal. European Journal of Law and Economics, 20(2), 127-144. http://dx.doi.org/10.1007/s10657-005-1733-2 
Smyth, R., \& Bhattacharya, M. (2003). How fast do old judges slow down? A life cycle study of aging and productivity in the Federal Court of Australia. International Review of Law and Economics, 23(2), 141-164. http://dx.doi.org/10.1016/S0144-8188(03)00029-2

Taha, A. (2004). Publish or Paris? Evidence of how judges allocate their time. American Law Economics Review, 6(1), 1-27. http://dx.doi.org/10.1093/aler/ahg009

Teitelbaum, J. (2006). Age and tenure of the justices and productivity of the U.S. Supreme Court: Are term limits necessary? Florida State University Law Review, 34(1), 161-181.

Vieira, L., \& Costa, S. (2013). Liderança no Judiciário: O reconhecimento de magistrados como líderes. Revista de Administração Pública, 47(4), 927-948. http://dx.doi.org/10.1590/S003476122013000400006

\title{
Authors' Profiles
}

\author{
Adalmir Oliveira Gomes \\ Campus Universitário Darcy Ribeiro, FACE, Bloco A, Asa Norte, 70910-900, Brasília, DF, Brasil. E-mail: \\ adalmirdeoliveira@gmail.com \\ Tomas Aquino Guimaraes \\ Campus Universitário Darcy Ribeiro, FACE, Bloco A, Asa Norte, 70910-900, Brasília, DF, Brasil. E-mail: \\ tomas.aquino.guimaraes@gmail.com \\ Luiz Akutsu \\ Campus Universitário Darcy Ribeiro, FACE, Bloco A, Asa Norte, 70910-900, Brasília, DF, Brasil. E-mail: \\ luiz.akutsu@gmail.com
}

